\title{
artículos
}

\section{La belleza física de la dama en El Decamerón de Boccaccio}

\author{
Alejandro Luque Lacaze
}

Investigador vinculado a la UMA

\section{RESUMEN}

La belleza física de la dama constituye un tema de singular relevancia dentro de los estudios transversales en Literatura e Historia del Arte. Adoptando como hilo conductor del discurso, el texto de los cuentos del Decamerón de Giovanni Boccaccio (1313-1375), el presente trabajo postula la interacción entre las descripciones escritas y las visiones pintadas por los grandes creadores del Renacimiento.

PALABRAS CLAVE: Mujer/ Género/ Iconografía/ Pintura/ Literatura/ Renacimiento/ Cultura/ Boccaccio/ Botticelli.

\section{La belleza física de la dama en El Decamerón de Boccaccio}

ABSTRACT

Woman's Beauty -the dame in particular-is one of the most relevant subjects into Literature and Art. Through pages of Giovanni Boccaccio's Decameron, this work describes and analyses relations and connections between written descriptions and painted images made by the most significants poets and artists into Italian Renaissance.

KEYWORDS: Woman/ Genus/Iconography/Painting/Literature/ Renaissance/ Culture/ Boccaccio/ Botticelli.

La visión de la mujer que, tradicionalmente, ha aportado el Arte está estrechamente ligada al desarrollo histórico de las relaciones sociales y de género, que, de manera precisa, refleja la literatura profana de la época, convirtiéndose así ésta en una fuente indispensable para el conocimiento y estudio de la intensa mirada del hombre hacia el universo femenino.

Dentro de un trabajo personal más extenso ${ }^{1}$, inscrito dentro de una investigación general estrechamente ligada a nociones religiosas, antropológicas y políticas que oscila desde la Edad Media hasta el siglo XV acerca de la belleza física de la dama, y la mirada masculina hacia la mujer a través de la Literatura profana y su interacción con el Arte, en el presente trabajo analizamos, a través de Bocaccio, uno

\footnotetext{
* LUQUE LACAZE, Alejandro: "La belleza física de la dama en El Decamerón de Boccaccio”, en Boletín de Arte $\mathrm{n}^{\circ}$ 32-33, Departamento de Historia del Arte, Universidad de Málaga, 2011-2012, págs. 387-414. Fecha de recepción: Febrero de 2010.

1 LUQUE LACAZE, Alejandro: La belleza física de la dama. Traslación de la Literatura a la Pintura (siglos XII al XV), Tesis Doctoral inédita defendida en octubre de 2009. Facultad de Filosofía y Letras (UMA). Calificación: Sobresaliente cum laude por unanimidad. Director: Pf. Dr. Juan Antonio Sánchez López.
} 


\begin{tabular}{|c|c|}
\hline 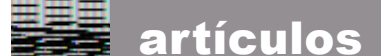 & Alejandro Luque Lacaze \\
\hline
\end{tabular}

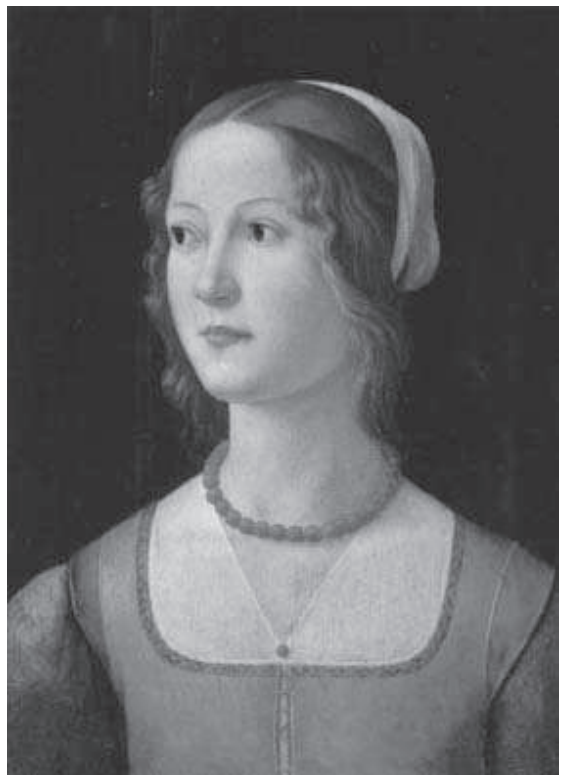

1. Domenico Ghirlandaio. Retrato de una joven dama. Calouste-Gulbenkian. Lisboa.

de los autores más destacados del Renacimiento, una conocida parcela -la de los estereotipos femeninos en el Arte- a través de una de sus obras literarias más célebres, El Decamerón. No obstante, aunque nuestro propósito inicial haya sido desvelar el ideal físico de la mujer, no hemos dejado de analizar lo que íntimamente se haya ligado a éste y su concepción de belleza según el entramado cortés.

\section{La Obra.}

Entre las obras de Boccacio en vulgar destaca El Decamerón, ${ }^{2}$ comenzada en 1348. Se trata de una obra que contiene cien cuentos relatados en diez días por varios protagonistas. La obra está escrita para un público culto, joven, refinado y rico, marcado por un comportamiento "decente", pero lejos de asustarse por las estrecheces de mira impuestas por la religión en el momento ${ }^{3}$, de ahí su temática libre y escabrosa. Se trata de una obra que celebra el gozo de vivir y amar en los tiempos difíciles de la peste.

La obra está marcada por un profundo neoplatonismo ${ }^{4}$, donde la cortesía es el ideal, el paraíso y la realidad es el imperio de los sentidos, lo terrenal. En el mundo terrenal, se ubica el paraíso y el infierno, es decir el premio y el castigo. Luego se asiste a dos visiones distintas y contrapuestas en la obra de Boccaccio: la visión ideal ytrágica expresada en lo "sacro-profano" del ideal cortés y la visión sensual, terrenal y vulgar, expresada en el mundo cotidiano de lo urbano y sus antihéroes. Sería muy interesante preguntarse si este fenómeno ocurre en la pintura de la época con el dilema de opción entre la Venus Urania o la Venus Pandemos ${ }^{5}$. En nuestro caso, la

2 BOCCACCIO, G.: Decamerón. Dirección literaria y prólogo J. García Pérez. Versión J.Ribera. Barcelona Editorial Ferma, 1965.BOCCACCIO, G.: Opere di B. Decameron, Rime. Filostrato. Elegía di MadonnaFiammetta. Ninfale Fiesolano. Corbaccio. A cura di Cesare Segre, commento di MaríaSegre Consigli e Antonio Benvenuti, Milán, Mursia, 1972.BOCCACCIO, G.: Opere in versi. Corbaccio. In laude di Dante. Prose latine. Epistole. A cura di Pier Giorgio Ricci, Ricciardo Ricciar-di Ed., Milán, Nápoles, 1965.BOCCACCIO, G.: La Elegía de Madonna Fiammetta / Corbacho. Introducción, traducción y notas de Pilar Gómez Bedate. Barcelona, Planeta, 1989.

3 HOLMES, G.: Florencia y Roma y los orígenes del Renacimiento. opus cit.,pág.471.Véase la presión que ejerció Savonarola y su ola de puritanismo en Florencia.

4 WITTKOWER, R. y M. Nacidos bajo el signo de Saturno. Madrid, Cátedra, 1982, págs. 160-63.

5 WIND E.: Los misterios paganos del Renacimiento. opus cit.,págs. 141-151. WIND E.: Los misterios 
Venus carnal no es del gusto de nuestros protagonistas narradores, ya que están anclados en el ideal de cortesía, pero sí que parece serlo del autor, ya que se deleita narrando episodios carnales.

Es el Decamerón una obra que expresa la visión que tiene Boccaccio de la vida y el mundo a través de historias, narraciones y retratos. Según la misma, el hombre es abandonado a su mundo sensible, real y cotidiano, donde tiene que valerse por su propia fuerza, y donde es movido por sus apetitos (ya sean altos o bajos), un hombre en suma que está limitado por sus pasiones, sometido a los vaivenes de la Fortuna y debe defenderse ante la inteligencia de sus adversarios, luego su defensa estará en su propia astucia, inteligencia y habilidad. Existe la crueldad en relatos cómicos donde los personajes astutos, alejados del ideal de virtud, se ríen de los torpes. De ahí que existan tantas historias con final feliz como triste.

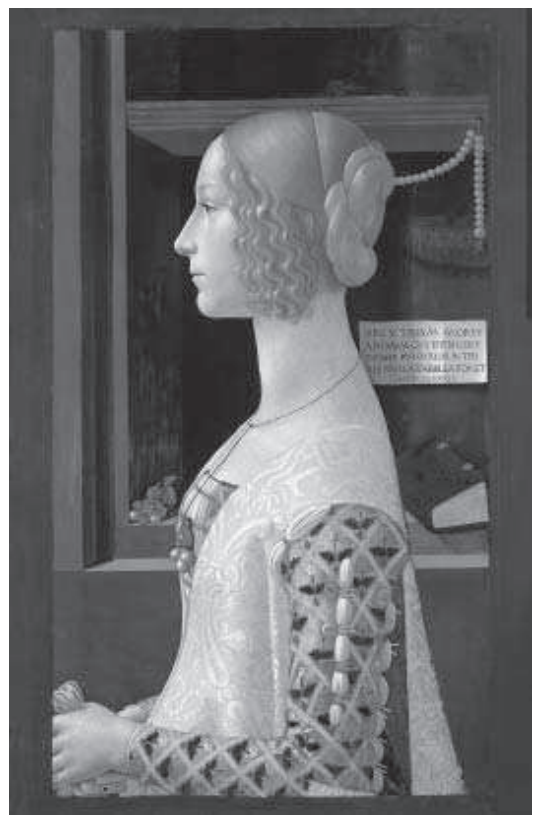

2. Domenico Ghirlandaio. Retrato de Giovanna Tornabuoni. Museo ThyssenBornemisza. Madrid.

El contexto histórico delimita significativamente la obra, ya que cabe encuadrarla dentro del ideal cortés, que creó la aristocracia en el siglo XII en Francia, pero que adoptó la burguesía en el siglo XIV, en la época de los Comune, que intenta recuperar y resucitar el ideal de la Edad Media. Es la absorción del mundo feudal, en donde no era compatible el amor y el matrimonio, y la virtud sólo podía ejercerse en la clase alta. En el mundo de los Comune, que es el mundo del comercio y la burguesía, el amor sí va unido al matrimonio y la virtud también es asequible para la clase llana. El ideal cortés se basaba en vivir libre de vicios, ejercitando el amor y las virtudes como la generosidad, magnanimidad, reconocimiento del mérito ajeno, el ingenio o la conquista de la simpatía en los demás. A este ideal cortés se liga estrechamente la vida urbana, donde los héroes corteses se diferenciarán del vulgo a través de sus sentimientos, sus actuaciones y virtudes.

paganos del Renacimiento. opus cit.,págs. 141-151.LEÓN COLOMA, M. A.:"Venus entre el cielo y la tierra: Imágenes simbólicas y degradantes para una diosa" en SAURET GUERRERO, T. (coord.): Historia del arte y mujeres. Málaga, Universidad, 1996, págs. 121-152. 


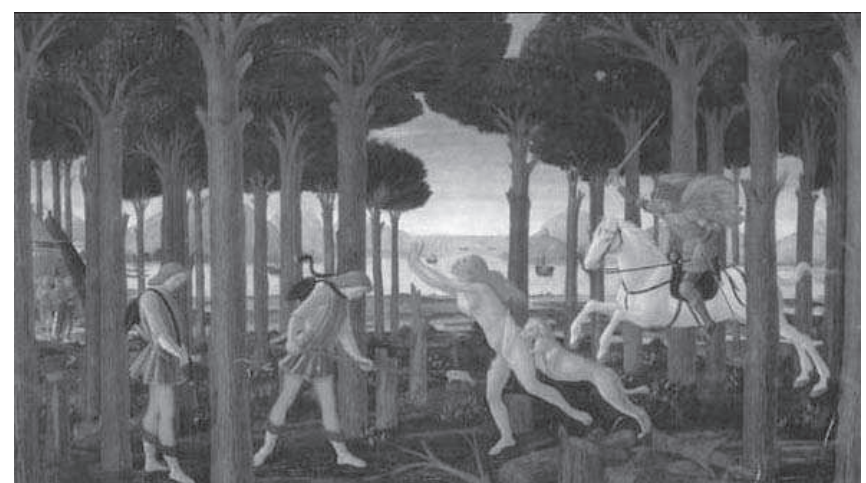

3. Sandro Botticelli. Historia de Nastagio degli Onesti. Primer Episodio. Museo del Prado. Madrid.

El amor es junto a la magnanimidad, que es liberalidad en dar y alegría en la adversidad, la manifestación más alta del ideal cortés. El que se enamora es noble de espíritu, y es más alto socialmente cuanto la amada sea de rango más noble.

El argumento introductorio y columna vertebral donde se ramifican las historias versa en torno a una reunión de jóvenes, donde prevalece la mayoría femenina: siete damas de 18 a 28 años y tres hombres de 25. La reunión tiene lugar en una idílica villa de ocio en la Toscana. Durante quince días estos jóvenes se retirarán del peligro de la peste que acaece sobre Florencia y se distraerán en dicha villa contando diez relatos diarios, uno por cada personaje, durante el espacio de días que dure el retiro, intercalando días de recreo basados en descansar en la naturaleza, en comer, en danzar y en cantar.

Los cuentos se relatan en las horas de sobremesa, y además por turnos, cada día de la semana menos los viernes y los sábados, y uno por cada protagonista. Eligen también diariamente un rey o una reina que dirija el grupo y decida el tema de los cuentos para el día siguiente; solo el primer día y el noveno, los narradores tienen libertad para contar lo que quieran, el mismo privilegio se le concede a Idóneo, que además será el último en intervenir con su relato. Los temas abarcan todos los aspectos posibles de la vida: se empieza con las circunstancias de la fortuna, pasando a las aventuras de amor, ya sean felices o infelices, se cuentan cuentos sobre la habilidad y el ingenio, también sobre las burlas que demuestren la inteligencia y por último cuentos que destaquen las virtudes caballerescas. Los diez narradores poseen rasgos individuales y tienen nombres simbólicos: Pánfilo, es la personificación del amante, Filostrato, simboliza al amante infeliz, e Idóneo al amante vividor. Entre las jóvenes destacan, aparte de la joven Fiammetta, que encarnaría a la amada real que tuvo el autor, a Pampinea, por ser la mayor de edad e inteligencia y Neifile, por ser la 


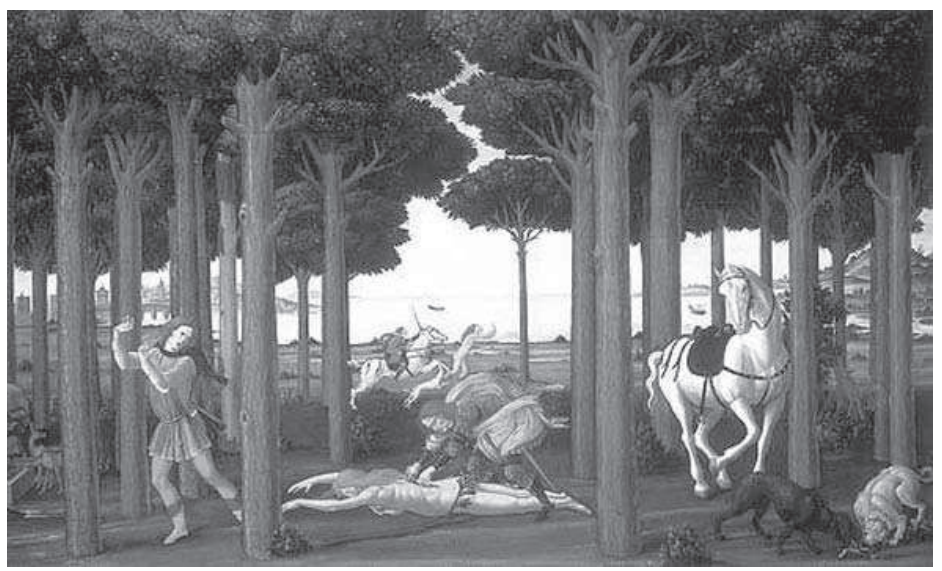

4. Sandro Botticelli. Historia de Nastagio degli Onesti. Segundo Episodio. Museo del Prado. Madrid.

jovencita y la más inexperta. De las demás no se habla con rasgos concretos.

\section{LA MUJER Y LOS TRES TIPOS DE BELLEZA.}

La mujer aparece representada en el Decamerón encarnando tres clases de belleza diferenciadas, la primera sería la belleza prototípica, que es la imagen que ha prevalecido desde los trovadores pasando por Dante o Petrarca, en segundo lugar la belleza que denominaremos carnal y por último la belleza exótica como algo excepcional.

Es importante señalar las visiones de la mujer que señala Paola Ventrone en sus estudios sobre la mujer florentina, su progresivo paso de donna a dama y de dama a ninfa ${ }^{6}$. Si partimos de esta reflexión, la mujer donna, sería la que se inscribiría en el marco cronológico anterior al 1460, estando caracterizada por mantenerse sometida al padre y al marido, dedicada a la familia y al cuidado de la casa, y al funcionamiento de la economía doméstica, mujer devota y púdica, dividida entre la opción del matrimonio o el convento ${ }^{7}$.

6 VENTRONE, P.: Simonetta Vespucci e le metamorfosi dellimmagine della donna nella Firenze dei primi Medici, opus cit., pág.719.

7 Véanse KAPLISCH-ZUBER, C.: La famiglia e le donne nel Rinascimento a Firenze, Roma-Bari, Laterza,1988. FABBRI, L.: Alleanza matrimoniale e patriziato nella Firenze del '400. Studio sulla famiglia Strozzi, Firenze, Olschki, 1991. MOLHO, A.: Marriage Alliance in Late Medieval Florence, Cambridge Mass. London, Harvard University Press, 1994. 


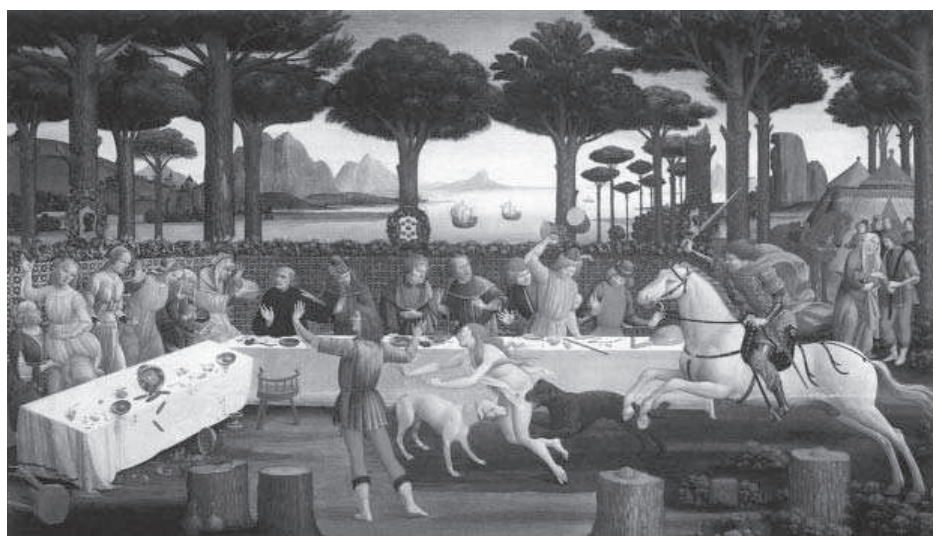

5. Sandro Botticelli. Historia de Nastagio degli Onesti. Tercer Episodio. Museo del Prado. Madrid.

\section{LA BELLEZA PROTOTÍPICA.}

La belleza prototípica nos refleja la importancia no abandonada aún del modelo antecesor que caracterizaba a la donna angelicata, o Venus Urania. En definitiva se trata de un ser de rasgos angelicales, una presencia etérea y "dorada" de carácter platónico ${ }^{8}$, encarnación de una idea perfecta, un ser destinado a la adoración casi religiosa, pero exento de ser alcanzado carnalmente. Para afirmar tales rasgos nos remitimos a la descripción de una de las protagonistas descrita como una belleza celeste y divina ${ }^{9}$, u otras que parecían más ángeles que mujeres ${ }^{10}$, o la afirmación en la expresión que ni los ángeles pintados ${ }^{11}$ lo cual nos conecta directamente en la relación entre el aspecto físico femenino ideal con el del ser asexuado y espiritual que es el ángel, e incluso de su función de mensajero divino. Veíamos, pues, que esta asociación existía en la pintura desde Giotto, y es a ella a la que nos intenta remitir el autor en tales descripciones. Incluso en un ámbito profano estas figuras religiosas se sustituirían por la de personajes mitológicos como los céfiros ${ }^{12}$ que adoptan la iconografía y el mismo aspecto angelical y que tan bien pueden ilustrarse con la obra de Lippi o Botticelli.

Todo esto enlaza con la idealización neoplatónica de la década 1470-1480 que corresponde fundamentalmente a dos figuras históricas: Albiera degli Albizzi y Simoneta

8 GOMBRICH, E. H. Imágenes simbólicas. Estudios sobre arte del Renacimiento. opus cit., pág. 484. Véase págs. 71, acerca de los diálogos de Platón que hablan de dos Venus o el poema de Lucrecio.

9 BOCCACCIO, G.: Decamerón. opus cit.,pág. 276.

10 BOCCACCIO, G.: Decamerón. opus cit.,pág. 628.

11 BOCCACCIO, G.: Decamerón. opus cit.,pág. 262.

12 BOCCACCIO, G.: Decamerón. opus cit.,pág. 479. 


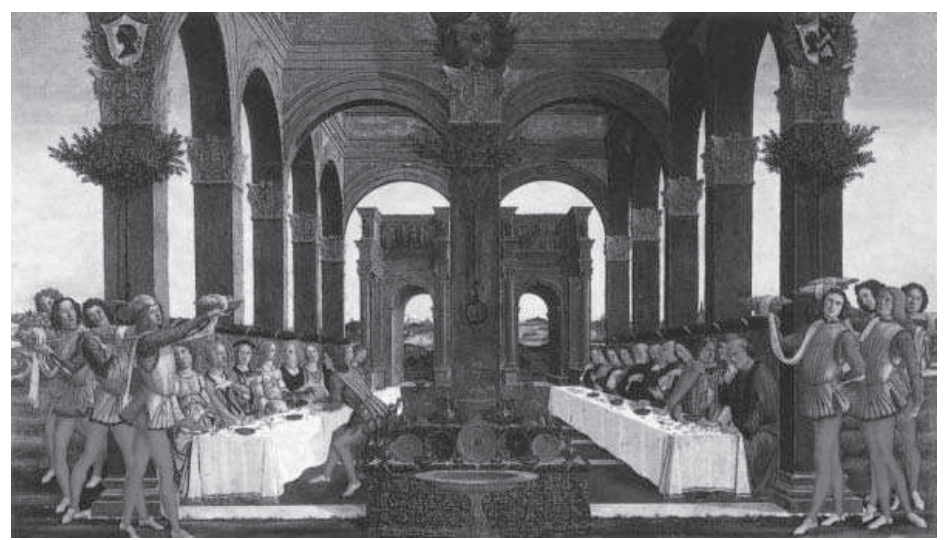

6. Sandro Botticelli. Historia de Nastagio degli Onesti. Cuarto Episodio. Galería del Palazzo Pucci. Florencia.

Cattaneo Vespucci. Ya hemos comentado anteriormente que el rol de amor cortés reservado a la dama no era negativo, sino que sirve de pauta social. Según Ventrone se ha pasado donna a dama y de dama a ninfa, en lo que particularmente nosotros vamos a denominar belleza prototípica ${ }^{13}$. Donde el término donna alude a una posible madurez sensual, en contraposición a la condición de fanciulla inexperta en cosas de amor ${ }^{14}$.

La ninfa será pues, la transfiguración ultaterrena de un códice o lenguaje de distinción, un símbolo literario, una nueva manera de vivir donde el neoplatonismo configura una visión de la mujer ideal cuya fisonomía debería representarse metafísicamente y sin encarnar en una fijación visual predeterminada. Se trata, en suma, de una representación icónica de contenido trascendental. Se elige para encarnar esta belleza de elaboración literaria neoplatónica a Simonetta ${ }^{15}$ y a Giovanna, cuya fisonomía permiten advertir la obra de Botticelli o Ghirlandahio. La primera es una belleza femenina fundada, por un lado en la muerte prematura de la joven a los 23 años de tisis, abril de 1476 y dos, en la idealización literaria propia de su personaje y contexto histórico. Para ello, se toma como excusa la fuente literaria mitológica: la ninfa, desnuda, con velo y cabello suelto, como veremos en las historias y personajes del Decamerón perfectamente representadas. Se trata además de nobles bellezas, hijas de grandes familias mercantiles. Y sirven como síntesis icónica de la cultura

13 P. VENTRONE: Simonetta Vespucci e le metamorfosi dell'immagine della donna nella Firenze dei primi Medici, opus.cit., pág.26.

14 TOMASSEO N. et BELLINI,B.: Dizionario della lingua italiana, Torino, UTET, 1865. WARBURG, A.: "Delle «imprese amorose» nelle più antiche incisión fiorentine". en La rinascita del paganesimo antico. Contributi alla storia della cultura, raccolti de G. BING, Firenze, La Nuova Italia,1966, págs. 179-191.

15 TOMASSEO N. et BELLINI,B.: Dizionario della lingua italiana, Torino, UTET, 1865. WARBURG, A.: "Delle «imprese amorose» nelle più antiche incisión fiorentine". en La rinascita del paganesimo antico. Contributi alla storia della cultura, raccolti de G. BING, Firenze, La Nuova Italia, 1966, págs. 179-191. 
neoplatónica de los años 1470-1480 y de la postura general postula da por nuestra investigación en cuanto al esfuerzo de la época por aunar belleza y rango. La ninfa se diferencia del prototipo de donna oligárquico por asumir el papel de rasgo idealizado:

Candor erat dulci suffusus sanguine, qualem alba ferunt rubris lilia mixta rosis.

Ut nitidum laeti radiabant sideus ocelli, saepe Amor accensas rettulit inde faces. Solverat effuses quoties sine lege capillos, infesta est trepidis visa Diana feris; sive iterum adductos fulvum collegit in aurum, compta Cytheriaco est pectine visa Venus. Usque illam parvi furtim componere Amores sunt soliti et facili Gratia blanda manu, atque honor et teneri iam cana modestia vultus, et decor, et probitas, purpureusque pudor, casta fides, risusque hilaris, Moresque pudici, incessusque decensa, nudaque simplecitas ${ }^{16}$.

Conserva sin embargo los valores de la modestia, pudor, decoro del vestido propio de la mujer del tiempo oligárquico.

Il suo colorito era candido e soffuso di lieve rossore, come bianchi gigli misti a rose rosse. Gli occhi sorridevano, brillando come stelle lucenti; spesso Amore accendeva le sue fiaccole al loro fuoco. Ogni volta che lasciava sciolti e liberi i suoi

capelli, assomigliava a Diana, nemica delle timide fiere; e quando di Novo li raccoglieva in un nodo dorato, sembrava Venere pettinata dal pettine di Citera. Anche

gli Amorini solevano adornarla furtivi, e con essa le dolci Grazie, con mani affettuose;

l'adornavano la fama, la modestia, superiore all'età del suo giovane volto, la dignità,

l'onore e il rossore pudico, la casta fedeltà, il riso spontaneo, i buoni costumi, l'andatura signorile, la schietta semplicità... ${ }^{17}$

Los años de asentamiento en el poder de Lorenzo son 1473-1474, tras la revuelta de los Volterra y la difícil responsabilidad de heredad de su padre Piero. No obstante, se consolida como príncipe civil dedicándose a la cultura y las letras,

16 PAOLA VENTRONE, pág.: Simonetta Vespucci e le metamorfosi dell'immagine della donna nella Firenze dei primi Medici. opus cit., pág. 26.

17 POLIZIANO,A.: In Albieram Albitiam, pág. 91. 
afianzando su imagen cultural y política a través de Ficino y acogiendo en su casa al joven Poliziano, donde otra nueva imagen femenina aparece deslumbrante: Giovanna degli Albizzi. Al igual que Simonetta, ésta muere prematuramente también. La fanciulla, prometida con el patricio Sigismondo Lotteringhi Della Stufa, muere con quince años de pulmonía el 14 julio de 1473, después del baile organizado en honor de Eleonora de Aragón a su caso a Florencia.

Entre las más señaladas representaciones de la ninfa destacarían la hipotética galería de retratos que se atribuyen a Simonetta, el busto de mármol atribuido a Verrocchio o la Cleopatra de Piero di Cosimo, o la serie de tablas de Botticelli. Asimismo como identificación de Marietta se propone la imagen de busto de Desiderio da Settignano y Verrocchio, Esmeralda Brandini de Botticelli, o las propias imágenes de Giovanna Tournabouni de Ghirlandaio en Santa Maria Novella.

Por otra parte tendríamos otro ideal de belleza en la dama real Lucrecia Donati, la cual podemos encontrar sus rasgos en minuciosas descripciones de Polifilo sino también en la obra de Botticelli, en la Gracia de la belleza, al ser identificada la primera por la derecha en la Ronda de las Gracias de la Primavera y en la Venus Genitrix del mismo cuadro, asimismo en la Madonna del Magnificat o la Venus del cuadro de Venus y Marte de la National Gallery de Londres. Además se conocen los rasgos de Lucrecia por la identificación de la Gentildonna dalle belle mani de Verrochio, esta identificación lleva a la rectificación de la Ginevra de Benci de Leonardo donde la atribución habitual a Verrocchio se pone ahora en duda ${ }^{18}$.

Se ha señalado que no hay que obsesionarse en buscar la imagen literal de las representaciones, pero bien es cierta la evidencia que existe una trasposición real literaria a la imagen icónica que es lo que estudiamos. Aunque se trata de un prototipo filosófico, vemos cómo tales arquetipos se han inspirado físicamente en modelos de la Antigüedad. En este plano filosófico, los ojos luminoso come stelle, aluden a la inteligencia de la mente y a la pureza del corazón, se hace hincapié en el armónico movimiento del cuerpo, reforzado en la ondulación del vestido y abandonando el estilo alla francesa, en favor de la recuperación del pathos a la anticca. Al ver las pinturas advertimos la literalidad de estas descripciones ${ }^{19}$.

Lo que sí es cierto es que éstos programas pictóricos, puramente florentinos, se basan en complicadas alegorías inspiradas en las fábulas mitológicas, que son cristianizadas a través de lecturas en clave, y llevadas a cabo por Ficino y los intelectuales del círculo neoplatónico. Por tanto, solo son posibles de interpretar bajo las indicaciones de los propios humanistas. El arte cumple así una función social

18 KRETZULESCO, K.; LYAUTEY, pág.; GOEBEL-SCHILLING: Los jardines del sueño: Polifilo y la mística del Renacimiento. Siruela, Madrid, 2005 pág. 372.

19 WARBURG, A.: Delle «imprese amorose» nelle più antiche incisioni fiorentine. Véase el capítulo dedicado a "L'ingresso dello stile ideale anticheggiante nella pittura del primo Rinascimento", págs. 283-307 
cuyos jeroglíficos solo estarán al alcance de los elegidos; en otras palabras patricios intendentes que habían cambiado, en menos de dos décadas, las pinturas religiosas por estas obras de una "elevación"distinta ${ }^{20}$.

La imagen-icono de Simonetta, vino a ser configurada entre Poliziano y Botticelli, es decir la clave de que la literatura y la pintura iban codo con codo retroalimentándose, y me atrevería a sugerir que la primera llevaría de la mano a la segunda. Veamos este ideal de belleza neoplatónica en la descripción de Eurídice contenida en la Fabula de Orpheo, compuesta a finales del 1473:

Ma io ho vista una gentil donzella che va cogliendo fiori intorno al monte.

I' non credo che Vener sia più bella, più dolce in acto o più superba in fronte: e parla e canta in si dolce favella che i fiumi isvolgerebbe inverso il fonte; di neve e rose ha 'l volto e d'or la testa, tutta soletta e sotto bianca vesta.

Aparecen los siguientes patrones que vamos a ver cumplidos en los personajes de Boccaccio: vestido blanco, símbolo de la pureza, encarnación piel candido y rosato larga cabellera dorada que señala a la figura de Albiera, así como al cuento boccacciano Ninfale fiesolano. En síntesis, supone el ideal femenino puro, no terreno, donde se alude a la superación del instinto, se doma a la razón y el intelecto, al sentido, y la ninfa cumple una función iniciática, su rol recupera el antiguo gusto por la anatomía del cuerpo y el movimiento, así como el cabello al viento, según advertimos en las obras de Botticelli, Antonio del Pollaiuolo y Verrocchio ${ }^{21}$.

Para ello la mitología y su simbología se utilizarán a menudo por Poliziano, como la descripción de Simonetta como Pallas según la emblemática del Quattrocentto, de donde obtenemos pruebas literarias del momento y su correspondiente imagen pictórica. Véase el capítulo donde Giuliano, hijo de Piero de Medici, va de caza, sigue

20 VILLA, C.: "Per una lettura Della "Primavera". Mercurio "retrogrado" e la Retorica nella bottega di Botticelli", en Strumenti critici, XIII ,1998. LA MALFA, C.: "Firenze e l'allegoria dell'eloquenza: una nuova interpretazione della Primavera di Botticelli", en Storia dell'arte, 97,1999, págs. 249-293. REALE, G.: Botticelli. La "Primavera"o le "Nozze di Filologia e Mercurio"? Rilettura di carattere filosofico ed ermeneutico del capolavoro di Botticelli con la prima presentazione analitica dei personaggi e dei particolari simbolici, Rimini, Idea Libri, 2001. MELTZOFF, S.: Botticelli, Signorelli and Savonarola. "Theologia Poetica" and Painting from Boccaccio to Poliziano, Firenze, Olschki, 1987, págs. 99-283.

21 VENTRONE, pág.: "Philosophia. Involucra fabularum": la "Fabula di Orpheo" di Angelo Poliziano, en Scritture per la scena" edición de A. CASCETTA, en Comunicazioni sociali», XIX ,1997, n. 2, págs. 137-180. POLIZAINO, A.: L'Orfeo ,Padova, Antenore, 1986. MARTELLI, M.: Angelo Poliziano: storia e metastoria, Lecce, Conte, 1995. BETTINZZOLI, A.:" Rassegna di studi sul Poliziano (1972-1986)", en Lettere italiane XXXIX ,1987. LORENZO di MEDICl: Comento de' miei sonetti, en Opere, edición de T. ZANATTO, Torino, Einaudi, 1992. MARTELLI, M.: Angelo Poliziano. "II mito d'Orfeo nell'età Laurenciana" en Interpres, VIII,1988. GHINASSI, G.: Il volgare letterario nel Quattrocento e le "Stanze" del Poliziano, Firenze, Le Monnier, 1957. 
a una cierva y ésta se metamorfosea en Simonetta. El joven se enamora tras sentir las flechas de Cupido y aprende el amor ideal. Esta narración, da forma alegórica a la iniciación en la pureza de amor de Giuliano. Desarrollando algo más el argumento anterior, el joven durante una partida de caza, muy devoto a Diana, no ha probado aún el sentimiento amoroso. Se lanza tras la referida cierva y al punto de la captura aparece una espléndida ninfa, explícitamente identificada con Simonetta Vespucci, de la que se enamora al momento. Cupido ha sido el responsable, aunque su sentimiento no podrá ser más que ideal y casto. Con ello empieza una batalla interior consigo mismo para vencer a Amor. Debe, pues abandonar la vía activa por la forma contemplativa, es decir, la vía cristiana hacia la virtud, que insta al intelecto a llevar el control sobre al sentido. Estando casada, no podía ser de otro modo. La pureza de amor se impone, ya que Simonetta no habría podido corresponder al sentimiento de otra naturaleza, por eso se reviste de Palas en su castidad.

Descripción de Simonetta como Palas:

Nella sonmità era un sole et nel meço di questo stendardo era una figura grande

simigliata a Pallas, vestita d'una veste d'oro fine infino a meço le gambe, et disocto una

veste biancha onbreggiata d'oro macinato et uno, paio di stivaletti açurri in gamba; la

quale teneva i pie' in su due fiamme di fuocho, et delle decte fiamme usciva fiamme che

ardevano rami d'ulivo che erano dal meço in giù dello stendardo, che dal meço in su

erano rami sença fuocho. Haveva in capo una celata brunita all'antica e' suoi capelli

tucti atrecciati che ventolavano. Teneva decta Pallas nella mano diricta una lancia da

giostra e nella mano mancha lo scudo di Medusa; et apresso a decta figura un prato

adorno di fiori di varij colori che n'usciva uno ceppo d'ulivo con uno ramo grande, al

quale era legato uno dio d'amore cum le manidirieto cum cordoni d'oro, et a' piedi

aveva archo, turcasso et saecte rotte. Era conmesso sul ramo d'ulivo, dove stava legato

lo dio d'amore, uno brieve di lectere alla françese d'oro che dicevano "la sans par". 
La sopradecta Pallas guardava fisamente nel sole ch'era sopra a llei ${ }^{22}$

Las características físicas más evidentes las enumera, sin embargo, Boccaccio en el Decamerón mediante la descripción de cuatro personajes femeninos concretos.

La primera en importancia es Fiametta, ya que se asocia a la amada real de Boccaccio, y que a diferencia de Dante o Petrarca fue un amor consumado. Su descripción aparece en la conclusión de la cuarta jornada donde comienza el reinado de este personaje:

Púsose de pie, se quitó la corona de laurel, y la colocó sobre la rubia cabeza de

Fiammeta, mientras decía:

-Te entrego esta corona, por ser tú quien mejor sabrás hacer olvidar la jornada

hoy a estos compañeros nuestros, con la que nos brindareis mañana.

Fiammetta, la de los largos cabellos de oro, cayéndoles suaves y desordenados

sobre los blancos hombros, cuyo rostro redondo y fresco tenía una semejanza de lirio $y$

de rosa, con unos ojos de halcón y la boca chiquita, y los labios que parecían rubies,

respondió...23

De esta descripción partiremos para hacer un esquema de los tópicos de belleza de la época: cabello rubio, larga melena desordenada, blancura de piel, boca pequeña, labios jugosos, rostro oval.

El segundo personaje en importancia será Ifigenia:

...aquella niña era el más bello objeto que pudiese ofrecerse a los ojos de los mortales; por lo tanto no cesaba de contemplarla. Elogió sus blondos cabellos, su

frente, su nariz, su boca, sus brazos, y sobre todo su naciente garganta, más blanca que

el alabastro ${ }^{24}$

22 MARTELLI, M.: Simbolo e struttura delle "Stanze", postfazione a Angelo POLIZIANO, Stanze cominciate per la giostra di Giuliano de Medici, Alpignano, Tallone, 1979. D,ANGHIARI, G.: "I Giornali (1437-1482)" en Letteratura italiana antica, III ,2002. RUGGIERI, R.M.: "Letterati, poeti e pittori intorno alla giostra di Giuliano de Medici" en Rinascimento, X ,1959. SETTIS, S.: "Citarea 'su un'impresa di bronconi”, en Journal of the Warburg and Courtauld Institutes, XXXIV, 1971.Sobre cartas del círculo de Lorenzo el Magnifico: MARTINELLI, M.: Studi laurenziani, Firenze, Olschki, 1965 MARTELLI. M.: « II sacco di Volterra e la letteratura contemporanea: storia di un'operazione di politica culturale ", en Rassegna volterrana, LXX ,1994; LARIVAILLE, pág. : "Nifo Machiavelli, principato civile », en Interpres, IX 1989.

23 BOCCACCIO, G.: Decamerón. opus cit.,págs. 323-324.

24 BOCCACCIO, G.: Decamerón. opus cit.,pág. 329. 
El tercer personaje sería Niccolosa, la que se describe:

...suelta la cabellera.....paréceme que te estoy viendo morderle los labios rojos y sus rosadas mejillas con tus dientes en forma de clavija de laúd ... ${ }^{25}$.

La cuarta referencia señala a dos personajes casi idénticos: Ginebra, la bella e Isotta, la rubia. Ambas son hijas del micer Neri, de las que poseemos los siguientes extractos:

... entraron dos jóvenes, de unos quince años de edad, rubias ambas y con el pelo graciosamente trenzado y coronado con una guirnalda de vincapervinca. Sus rostros

eran tan hermosos, y tan delicadas las facciones, que más parecían ángeles que

mujeres. Llevaban una túnica de tela de lino, de deslumbradora blancura, que no tenía

desde la cintura hasta arriba otros pliegues que los que naturalmente producían el talle

elegantísimo y una garganta redondeada por manos de amor: lo restante al bajar, se

ensanchaba en forma de pabellón y les caía hacia los pies...las náyades se zambulleron

hasta la mitad del cuerpo...el agua , que había pegado sus ropas al cuerpo permitía ver

todos sus contornos y demás partes; y pasaron por delante del rey más tímidas porque estaban más bellas...

Volvieron a aparecer con nuevo atavío, aunque no menos seductor que el primero. Un ligero tafetán cubría sus delicados miembros. Las dos llevaban, en fuentes

de plata, frutas de la estación que colocaron en frente del monarca, y habiéndose

retirado de la mesa, desplegaron las dulzuras de su voz armoniosa... el rey creía oir

cantos angélicos... ${ }^{26}$

Tal descripción nos remite directamente a la obra pictórica del Quattrocento, especialmente a la de Botticelli y Ghirlandaio, donde se hace la ubicación de la belleza femenina ideal dentro de un entorno natural o jardín sublime: el Edén o Paraíso, en las

25 BOCCACCIO, G.: Decamerón. opus cit.,pág. 582.

26 BOCCACCIO, G.: Decamerón. opus cit.,pág. 628- 629. 
nociones del hortus idealis y el locus amoenus que van indisolublemente ligadas.

$\mathrm{Si}$ atendemos al prototipo femenino creado por Botticelli, nos encontramos ante tipo de mujer rubia, con largos bucles ondulados que caen sobre las espaldas, con perfil exquisito y donde la nariz tiene una graciosa curva y los labios se doblan cerrando la boca sin provocación. Los ojos son de color verde claro. Los personajes de sus cuadros participan de esa isocefalia idealista y se repiten en todas sus obras. Y todo ello, sin mencionar el estilo o el pathos ${ }^{27}$ además de la influencia de la filosofía neoplatónica ${ }^{28}$ muy del gusto de los comitentes del momento ${ }^{29}$.

No se conoce ningún amor concreto del pintor, ni existen alusiones sentimentales. Existe la probabilidad de que compusiese su tipo femenino sintetizando facciones de varias mujeres, o que alguna mujer real le impactara tanto que repitiera su rostro. He aquí el problema de Simonetta Vespucci ${ }^{30}$. Simonetta Cattaneo, había nacido en 1453 , en Liguria, en Porto Venere según Polizaino, aunque otras tesis apuntan a Génova.

Estuvo casada con el banquero Marco Vespucci, familiar de Américo Vespucci y el matrimonio residió dentro de la corte de los Médici. Su padre era el noble genovés Gaspare Cattaneo, casado con Cattocchia. Brilló tanto en la Corte, que Lorenzo y Giuliano la consideraron la mujer más bella de aquel círculo. Según algunas hipótesis, los amores entre Giuliano y Simonetta aparecen ilustrados en las alegorías mitológicas de Botticelli como el cuadro Venus y Marte $^{31}$, ya que Botticelli fue pintor de cámara y artista predilecto de Giuliano como Verrochio lo fue de Lorenzo.

Simonetta morirá de tisis en el 1476 a los veintitrés años. Pasó siete años casada en Florencia con un comerciante florentino. La leyenda romántica insiste en la posibilidad de que el pintor estuviese enamorado en silencio y la retratase

27 GOMBRICH, E. H. Imágenes simbólicas. Estudios sobre arte del Renacimiento.opus cit.,págs. 63-131.

28 WIND, E.: La elocuencia de los símbolos. opus cit.,pág.124, sobre la filosofía del arte de Platón págs.41-63; págs. 81-85 para el tema derelitta de Botticelli.

29 WACKERNAGEL, M.: El medio artisco en la Florencia del renacimiento. Akal, Madrid, 1997. págs.201-284. Sobre los comitentes municipales, gremiales y privados, Pieri y Giovani de Medici; Lorenzo el Magnifico, Piero di Lorenzo, Lorenso di Pierfrancesco Medici.

30 Véase la obra PAOLA VENTRONE, pág.: Simonetta Vespucci e le metamorfosi dell'immagine della donna nella Firenze dei primi Medici, opus cit.,pág.719, págs. 7-49.

31 Se trata de una interpretación de la versión clásica del tema. La modelo fue probablemente Simonetta, donde algunos críticos advierten la enfermedad de la tisis en su rostro. En la interpretación se alude a que las abejas señalan directamente el escudo de los Vespucci, y la interpretación se presta a señalar el papel de la esposa que doma a su amante, en la interpretación romántica se interpreta que la escena hace alusión a un pasaje de la Giostra de Poliziano, en el que aparece Minerva con Cupido atado, símbolos de la Castidad, que se aparece a Giuliano en sueños. Véase GOMBRICH, E. H. Imágenes simbólicas. Estudios sobre arte del Renacimiento. opus cit., págs. 118-119. La Primavera. No se conoce la identidad de las mujeres llamadas a la izquierda junto a el personaje de Mercurio en Las Tres Gracias. Puede que una de ellas sea Simonetta, porque el ángel apunta a una de Las Tres Gracias, el personaje del centro es Venus: Urania y Genitrix, fuerza creadora y ordenadora en la naturaleza, y a la derecha Flora y Lascivia se encuentran perfumadas por un Céfiro. Existe, sin embargo, otro cuadro en el que el pintor representó a Simonetta como Venus naciendo de la concha donde se destaca el desnudo, otra es la Venus de Berlín. Se tratan de pinturas de tamaño al natural. Las pinturas se hallaban en Villa di Castelo en 1503. Las modelos bien pudieran desnudarse en una cura de aguas y servir de modelo en la casa Médici de Lorenzo. 
aún después de su muerte. Pero de tal teoría se desmarcan algunos investigadores como Horne o Mensil, que afirman de que no existe prueba alguna sobre que el pintor retratase a la joven esposa de Marco Vespucci. ${ }^{32}$

Descripciones físicas de Simonetta, muy parecidas a los tópicos literarios que hemos podido observar en nuestro estudio, podemos hallarlas en las Memorias de Lorenzo de Medicis:

Su cutis era extremadamente claro, pero no pálido; rosado, pero no rojo. Su porte

era serio, sin ser severo; dulce y placentero, sin asomo de coquetería o vulgaridad. Sus

ojos vivos, no manifestaban arrogancia ni soberbia. Su cuerpo era finamente proporcionado y entre las demás mujeres parecía de superior dignidad y, no obstante,

libre de toda clase de formalidad o afectación... ${ }^{33}$

Se ha apuntado a otra posible fuente, que bien pudiera ser Angelo Poliziano ${ }^{34}$, en cuya obra la Stanze per la Giostra se ha querido ver una alusión en clave alegórica de la relación que sostuvo Giuliano con Simonetta, en clave de amor platónico. Ya se quiso ver una alusión a Simonetta en El Nacimiento de Venus, de Botticelli, los poetas dieron alas a su imaginación alegando que éste se interpretaba como un homenaje a Simonetta Vespucci, aunque no existe ninguna prueba que lo demuestre.

Lorenzo estaba ocupado con los asuntos del Estado, pero su hermano menor tenía mucho tiempo libre, el suficiente para seducirla. En La Giostra, una obra compuesta en 1475 para celebrara la alianza entre Florecia, Venecia y Milán, donde se celebraba un torneo de justs organizado desde 1474. Los Médicis habían presionado a las familias nobles a la participación y se prestaron a sufragar los gastos de las armas y vestuario, entre los que figuran los estandartes. Según la tradición medieval estaban decorados con imágenes simbólicas difíciles de entender que simbolizaban alusiones a una elegida, y por tanto la domina de los sentimientos de los caballeros, según el código cortés que se mantuvo en la Florencia del cuatrocientos. Este amor recordemos, consistía en la elección de una dama ya casada de la corte que destacase especialmente por sus virtudes, entre las que se valoraba la castidad

$32 \mathrm{GOMBRICH}$, E. H. Imágenes simbólicas. Estudios sobre arte del Renacimiento.opus cit.,pág.484, pág 273

33 Véanse Memorias de Lorenzo de Medicis: MEDICIS, L.: Los Medicis, Barcelona, Ediciones B, 2002.

34 Angelo Poliziano y Marsilio Ficino era partidarios de transmitir enseñanzas a través de la belleza de imágenes bellas, es decir el uso del sermón pictórico a través de una alegoría moral disfrazada con un tema mitológico, como son las obras destinadas a Villa Castello de Lorenzo de Pierfrancesco de Médici .Véase la imprescindible obra VV. AA: Eros y magia en el Renacimiento: 1484. Madrid, Siruela, 1999. Y la escasa bibliografía en español de FICINO, M.: De amore. Comentario a el Banquete de Platón. Tecnos, Madrid, 1986. FICINO, M.: Tres libros sobre la vida; de la vida sobria. Madrid, Asociación Española de Neuropsiquiatría, 2005. FICINO, M.: Sobre el furor divino y otros textos. Barcelona, Anthropos, 1993. POLIZIANO, A.: Estancias. Orfeo y otros escritos, Madrid, Cátedra, 1984. 
y la capacidad de desdeñar al amante. Este juego servía de aprendizaje amoroso del caballero en su itinerario de la nobleza.

Estas banderolas o estandartes fueron encargados a afamados pintores, entre ellos Botticelli que hizo el de Giuliano, y éste, entró a las listas cargando uno de ellos, en el cual se veía una pintura de una figura femenina con los rasgos de Simonetta posando como una Palas Atenea vestida con una túnica blanca bordada en oro. Sus pies descansaban en llamas que consumían las ramas de olivo, mientras que las ramas en alto permanecían intactas. Armada con yelmo, lanza y escudo decorado con la cabeza de Medusa. Detrás del tronco del olivo Cupido atado con hilos de oro permanecía atado al árbol. Y en el tronco escrito con letras doradas en francés $L a$ Sans Pareille, (La Sin Par).

Toma pues el relato de la Giostra, donde Poliziano, como hemos citado anteriormente, describía el sueño de Giuliano en el que vió a Simonetta vestida con tunica blanca y sobre ella la armadura de Palas, que protegía su cuerpo de las flechas de Cupido, y su pecho era protegido por el escudo de Medusa. Ésta, furiosa, ató a Cupido a un árbol de olivo y destruyó sus flechas y su arco, entonces Cupido le imploró ayuda a Giuliano, que tras recibir el coraje de la Gloria, le quitó la armadura a Simonetta para poderla así portar el día del torneo ${ }^{35}$.

Así que más que a la alianza entre las ciudades, cuentan que todo había sido programado por los Médicis para que el joven pudiese impresiona a su dama con el manejo de las armas. Así que, no pudiendo ser de otro modo, Giuliano ganó el torneo y el afecto de la bella Simonetta, quien fue nombrada La Reina de la Belleza en ese encuentro. A raíz de este acontecimiento, algunos intérpretes dedujeron que había un romántico idilio entre ambos y que la diosa Venus pintada por Botticelli tenía los rasgos de Simonetta, natural de Porto Venere (el Puerto de Venus) en la costa de Liguria.

Ambos murieron poco después de la fiesta, Giuliano bajo las dagas de enemigos políticos en la conjura de los Pazzi, y Simonetta de tuberculosis, un año después, poniendo una nota trágica a la interpretación popular ${ }^{36}$. La ciudad entera cayó en un duelo por la bella Simonetta y miles siguieron en procesión su ataúd hasta el lugar donde fue sepultada. Su esposo se volvió a casar pronto y Botticelli terminó El nacimiento de Venus en 1485, nueve años después. Dentro de la leyenda se señala que la causa de la isocefalia de los rostros de las mujeres de los cuadros de Botticelli y su parecido con Simonetta sugieren que él también se enamoró de ella, esta hipótesis ha pretendido verse corroborada en la petición que hizo el artista de hacerse enterrar a sus pies en la Iglesia de Ognissanti -la iglesia de los Vespucci- en Florencia en 1510, 34 años después de la muerte de Simonetta.

En cuanto a Ghirlandaio, su belleza es más realista, no tan idealizada como la

35 RAQUEJO GRADO, T.: Boticelli. Madrid, Historia 16, 1993, págs. 44-45.

36 HAGEN, R.M. et R.: Los secretos de las obras de arte. opus cit.,pág.123 y pág. 94. 
de Botticelli. Lucrecia Donati o Giovanna degli Albizzi Tournabuoni serán las estrellas femeninas de los retratos en grupo de Ghirlandaio, que serían también mayoritariamente rubias. De entre todas brilla con luz propia en la corte, al igual que Simonetta, Giovanna Tornabuoni. Giovanna era hija de Lucrezia, también retratada por Ghirlandaio en un cuadro frío y soso, que pudo tener alta participación de los aprendices de su taller. Giovanna, la Bella Vanna, estaba casada con Lorenzo Tornabuoni, el hermano de Ludovica. Tenía solo veintitrés años cuando murió en el año 1488.

Giovanna aparece también en el retrato de la alta sociedad florentina que Ghirlandaio realizó con el pretexto de pintar la Aparición del ángel a Zacarías. La joven se había casado dos años antes y el retrato resulta un triste documento de su belleza, puesto que Giovanna moriría el mismo año que el pintor terminó el cuadro. La pose de la muchacha era típica del Quattrocento, de perfil sobre un fondo neutro, oscuro, que destaca la elegancia y hermosura de la joven. Ella está colocada sobre estructuras geométricas: un eje axial en mitad del cuadro, ángulo recto para su brazo y una suave pirámide para el cuerpo. Todo ello traduce una perfección ideal, que se hace eco en la alacena de fondo, toda ella construida con cuadrados y rectángulos. En la alacena hay más complementos que aluden a la perfección de la joven: la hilera de cuentas de coral, que simbolizan el amor a Cristo, las joyas y el libro, aficiones de las jóvenes de buena familia, y un letrero escrito en latín por el autor que reza:

\section{¿Podría el arte retratar su carácter y virtud?}

Ninguna pintura en el mundo podría ser más hermosa. $1488 .^{37}$

Para el prototipo de dama de la corte en Ghirlandaio véanse las damas de los frescos como Giovanna degli Albizzi en la escena de la Visitación. Por otra parte nos hallamos en un tiempo en el cual era muy común el caso del retrato de Vírgenes o santas tomando como modelos reales incluso muchas de estas modelos ${ }^{38}$.

Para la comprensión de este asunto, no podemos olvidar el caso de otra dama real, que sirvió como modelo de Virgen, el caso de Lucrecia Butti. El caso es especialmente curioso por lo escandaloso y por lo divulgado a través de la obra capital de Vasari. El pintor Lippi, teniendo 8 años, fue ingresado como monje en el convento del Carmine, allí tomó fama en las cosas manuales -en expresión de Vasari- y empezó a dibujar. Masaccio había pintado la capilla.

Posteriormente tomó los votos en 1421 a los 15 años, y existen documentos del convento que ya lo hacen constar allí hasta 1432. Se cuenta que le preocupaba poco la religión y que Cosme de Médicis fue su protector y realizó obras para la sacristía de Santa Croce:

37 Comprobemos la continuidad de los tópicos de belleza en la célebre obra del pintor, el retrato de Giovanna degli Albizzi de la colección Thyssen-Bornemisza.

38 Véase WÖLFFLIN. H: El arte clásico. Madrid, Alianza, 1985. Para el caso de las madonas florentinas de Rafael págs. 104-109 y las madonas y santos Andrea del Sarto en pág. 196. 
...Dicen que era tan apasionado, que cuando veía una mujer que le gustaba le habría dado todo lo que tenía para poder poseerla, y que cuando no lograba esto, entibiaba la llama de su amor

pintando su retrato. Y este apetito lo extraviaba a tal punto, que cuando estaba de tal humor

poco o nada se ocupaba de su trabajo. Así, en una ocasión en que Cosme de Médicis le estaba

haciendo pintar un cuadro en su casa, lo encerró para que no saliera a perder tiempo. Pero

Fray Filippo, después de quedarse allí dos días, se vio presa de un furor amoroso tan bestial,

que con unas tijeras cortó las sábanas de la cama y empleó las tiras para deslizarse fuera por la

ventana, entregándose luego durante muchos días a sus placeres. Cosme, al no encontrarlo, lo

hizo buscar y finalmente logró que volviera al trabajo, pero desde entonces le dio libertad de ir a donde quisiera, estando arrepentido de haberlo encerrado, puesto que era tan loco y podía haber corrido tan grave peligro....

....Mientras trabajaba en la tabla del altar mayor que le habían encargado las monjas de Santa

Margherita, vio un día a una hija de Francesco Buti, ciudadano florentino, que alli estaba, sea

como pupila, sea como monja. Fray Filippo, impresionado por Lucrezia -que tal era el nombre

de la joven, la cual tenía bellísima gracia y expresión-, tanto insistió ante las monjas que obtuvo permiso de pintar su retrato para ponerla como Nuestra Señora en la obra encargada. Y como con esta oportunidad se enamoró más aún de la niña, puso tantos medios en práctica que alejó a Lucrezia de las monjas y se la llevó el día mismo en que ella iba a presenciar la exhibición del Cinturón de Nuestra Señora, venerada reliquia de esa ciudad. Este hecho constituyó una gran vergüenza para las monjas, y Francesco, el padre de Lucrezia, perdió para siempre la alegría;

aunque hizo todo lo posible por recobrar a su hija, ésta, sea por miedo o por otra razón, nunca

quiso volver y se quedó con Filippo, el cual tuvo de ella un hijo varón, que también fue llamado

Filippino ${ }^{39}$.

39 VASARI, G.: Las vidas de los más excelentes arquitectos, pintores y escultores italianos desde Cimabue a nuestros tiempos (Antología), Estudio, selección y traducción de María Teresa Méndez Baiges y Juan María Montijano García, Madrid, Editorial Tecnos, 2006. 
Así Lucrezia, figura inscrita en el convento como monja desde 1454 junto a su hermana Spineta. Otras fuentes aluden que en 1456 fue raptada por un capellán del convento, lo cual señala a Lippi. Al parecer, su hermana y otras tres monjas que la buscaron la encontraron, y ésta regresó al convento en 1459. Mientras, por otro lado, se cuenta que hay datos que afirman que Lucrecia y su hermana estaban en casa de Filippo en 1461. Y que más tarde, en 1465 tendrían otra hija, Alessandra. Sobre el caso, existe una dispensa de votos que logró Cosme de Médicis para los dos del Papa Eugenio, quien en vida quiso dispensarlo, para que tomase como mujer legítima a Lucrecia.

Fray Filippo murió el 9 ó 10 de octubre de 1469 y a fray Diamante dejó en gobierno en su testamento a Filippino su hijo, el cual, niño de diez años, aprendió del arte de fray Diamante, con quien volvió a Florencia. Filippino fue acogido como discípulo por Sandro Botticelli. 40

Según los documentos el rapto es correcto. En realidad Lippi era capellán, y cuando en la exposición anual del Sagrado Cíngulo, se permitía a las monjas salir del convento y participar de las celebraciones, el capellán y la monja se escaparon a la casa que este tenía cerca. Las monjas no quisieron hacer escándalo, pero cuando huyeron también la hermana de Lucrezia, Spinetta Butti y poco después tres monjas más, se tomaron medidas, y se tardó mas de dos años en que volviesen al convento. Pero después, en menos de un año, y pese al arrepentimiento de ambas, las hermanas Buti se escaparon de nuevo. Se sabe que estaban ya instaladas en casa de Lippi en 1461, y será cuando el papa le releve de sus votos y así pierda todos sus cargos eclesiásticos e ingresos fray Filippo.

Lucrezia Butti tenía los rasgos ideales de juventud y belleza, de piel blanca, blonda, rostro oval, frente ancha y ojos claros que bien sirvieron para extender la imagen ideal de la dama florentina.

Sin embargo, en conclusión, acerca de tales personajes, podemos señalar dos aspectos, por una parte de la existencia de un ideal literario y filosófico de belleza, un arquetipo de belleza femenina, ligado a una época, finales del quatrocentto, y por otra parte que pese a su idealismo, este patrón se retroalimenta de modelos reales. Lo cual nos indica que por mucho que la mente sublime, el ojo del poeta o el pintor siempre hecha mano de lo que hay a su alcance para su referencia.

\section{LA BELLEZA CARnAL.}

Esta tipología de belleza correspondería a la nueva valoración sobre el universo femenino que surge en Boccaccio, donde las nuevas motivaciones apuntan hacia una tipología de mujer más real, carnal y tangible a través de los sentidos. Señalaría en definitiva, a la donna o mujer real. Este antecedente deriva de la situación de la mujer

40 WITTKOWER, R.et M.: Nacidos bajo el signo de saturno. opus cit., págs. 152-154 
vista en el Decamerón, a través de visión hedonista que surge en la ciudad tras la peste de 1348.

No en vano, este tipo de mujer robusta ya aparecía en algunas descripciones de los trovadores provenzales. Entre otras cuestiones, se pondera el caso de la estimación de las caderas anchas, para el mejor embarazo ya que ésta era la función primordial de la mujer. Asimismo, destaca la apreciación de la fortaleza y anchura de hombros, cualidades necesarias para desempeñar tareas masculinas caballerescas como las armas, la caza y el galope. De este ejemplo sobresale el personaje del cuento de El cornudo consolado, justo es decir que recuerda a las serranillas del Marques de Santillana ${ }^{41}$

....era una joven alta, robusta, de ojos vivos y pasiones ardientes, en una palabra de una

complexión tal, que necesitaba dos maridos y no uno... ${ }^{42}$

Pero no se refiere Boccaccio a este tipo de virtud, cuando habla de la cualidad carnal en sus protagonistas. Lo que el autor resalta es el goce carnal que el varón puede extraer y experimentar con este tipo femenino. Los ejemplos no abundan tanto pero son muy explicativos como lo es el personaje de Isabel es una mujer regordeta de cierta:

...frescura y buenas carnes ${ }^{43}$

En otro momento de la obra se elogia a una:

...joven y robusta, bella y rica ${ }^{44}$

Belcolore, una aldeana, se describe como:

...fresca y rolliza, bien moldeada ${ }^{45}$

Estas cualidades ya las habíamos resaltado en el caso de la belleza vulgar o Venus Pandemos en el primer capítulo. Un tipo de belleza contemplada en las clases bajas dentro de los trovadores y goliardos. Blancaflor, ya alude con su propio nombre a sus características físicas de buena moza ${ }^{46}$.

41 MARQUÉS DE SANTILLANA: Comedieta de ponza, sonetos, serranillas y otras obras, Barcelona, Crítica, 1997.

42 BOCCACCIO, G.: Decamerón. opus cit.,pág.383.

43 BOCCACCIO, G.: Decamerón. opus cit.,pág. 192.

44 BOCCACCIO, G.: Decamerón. opus cit.,pág. 467.

45 BOCCACCIO, G.: Decamerón. opus cit.,pág. 486.

46 BOCCACCIO, G.: Decamerón. opus cit.,pág. 550. 


\section{La Belleza eXótica.}

Por último comentaríamos la belleza-excepción aunque debiéramos de considerarla, más una "rareza", que una "belleza" en sentido estricto por pertenecer a otra raza, en este caso la árabe, que sería la protagonista del relato Gerbino y la princesa de Túnez.

...la rara belleza y las virtudes de la princesa sarracena... ${ }^{47}$.

La morena, está pues, escasamente representada. Es la llamada brunettina que sería la campesina que se lava la cara en la fuente y se adorna el cabello con flores silvestres en los poemas de Lorenzo y Poliziano. No obstante, Burckhardt señala cómo en su Ameto, Boccaccio nos describe a una mujer rubia y a una morena más o menos como las hubiera hecho un pintor de cien años más tarde.

En la morena (en realidad, "la menos rubia" de las dos) aparecen los rasgos que denominaríamos, según sus propias palabras, la spaziosa testa e distesa, implicando el concepto de unas formas amplias que trascienden con mucho al principio de "guapa»; sus cejas no forman ya dos arcos, como suponían el ideal de los bizantinos, sino que se muestran unidas juntamente en una sola línea; la nariz que describe parece aproximarse mucho a la aguileña y también el amplio pecho, los brazos moderados no cortos ni largos, o el efecto de la bella mano cuando se apoya purpúrea, son rasgos que ya anuncian esencialmente el concepto de belleza que tendría una época venidera, que a su vez se acerca inconscientemente al ideal estético de la Antigüedad. En otros fragmentos, menciona además Boccaccio una frente lisa (no redonda como en la Edad Media), unos ojos castaños serios y alargados, cuello redondo y terso, el tan moderno «pie pequeño» y el caso de una ninfa de cabellos negros brunettina ${ }^{48}$.

6. Boccaccio y el arte de su tiempo. El caso Botticelli: La historia de Nastaglio degli Onesti.

Los pintores más destacados del tiempo de Boccaccio y de los que nos hemos servido para nuestra investigación fueron Filipino Lippi, Botticelli y Ghirlandaio ${ }^{49}$. Ahora bien, cabe hablar de la curiosa relación que Boccaccio sostuvo con el gremio de su época. Para empezar parece sorprendente que dedique un episodio entero dentro del Decamerón a Giotto y su pintura en el cuento Giotto y el jurisconsulto ${ }^{50}$, pero aún se antoja

47 BOCCACCIO, G.: Decamerón. opus cit.,pág. 290.

48 BURCKHARDT, J.: La cultura del Renacimiento en Italia. opus cit.,pág.125. pág. 297. Véase WÖLFFLIN. H: El arte clásico. opus cit.,pág.761. Para el caso de los nuevos ideales de belleza pág. 237 y págs. 261-283; ARGAN, G. C.: Renacimiento y Barroco. vol II. Madrid, Akal, 1999.

49 GOMBRICH, E. H.: Nuevas visiones de viejos maestros, Madrid, Alianza, 1986. Ideal y tipo en la pintura italiana

renacentista ver págs. 91-122.

50 BOCCACCIO, G.: Decamerón. opus cit.,pág. 403. 
más curiosa la aportación de numerosos detalles que le vinculan con el gremio. Para ser más exactos ya existe un relato donde se explica el proceso de aprendizaje y oficio de los pintores y el paso que existe entre maestro s eocupaba un grado y otro además profundizar en de la relación, entre aprendiz y maestro: es el cuento Los bocetos de $\operatorname{Dios}^{51}$. También se alude en otro relato al carácter bohemio de los pintores tachándolos de pillos en el cuento Calandrino y el Conjuro amoroso ${ }^{52}$. Pero en este mismo relato, y sin desviarnos del tema, tampoco pasan inadvertidos los detalles que señalan los conocimientos que tenía Boccaccio de la conveniente ubicación de la obra de un pintor (el decorum). Véanse sobre el particular las recomendaciones de disposición de los temas de cuaresma en la sala de tertulia o el del Agnus Dei en el dormitorio.

Pero sin lugar a dudas la obra cumbre que remite a la influencia de la literatura sobre la pintura de la época queda bien ilustrada en la interpretación que Botticelli hace de la historia de Nastaglio ${ }^{53}$.

Botticelli, mantenía su propio taller desde 1470, en una época, hacia 1480 en la que sus cuadros ya eran muy valorados por los Medicis. El maestro se encargaba de la concepción de la obra y el dibujo de los paneles de madera, como señala Lightbown y confiaba los detalles, como los elementos decorativos, los trajes o los paisajes a sus ayudantes, entre ellos como hemos visto al hijo de Fra Filippo y Lucrecia Butti, Filippino Lippi. En este caso, la obra fue llevada a cabo en su mayoría por el taller de Botticellli. Según Lightbown, él solo pintaría la figura de Nastagio paseando en el bosque en el primer panel, mientras que Chastel limita su participación a la realización de los cartones y atribuye la ejecución a Bartolomeo di Giovani y Jacopo del Sellaio ${ }^{54}$.

El pintor, en un período de madurez artística, se inspiró en la inmortal obra de Boccaccio, para narrar una historia trágica de amor y muerte en cuatro cuadros al temple sobre tabla. Concretamente, el episodio que elige es la Historia de Nastagio degli Onesti. La serie fue

realizada para conmemorar el matrimonio de Giannozzo Pucci con Lucrezia Bini en 1483, celebrado en el palazzo Médicis en honor de Eleonora de Aragón. Antonio Pucci fue el que encargó al pintor decorar la habitación nupcial de su hijo Giannozzo (1460-97) que iba a contraer su segundo matrimonio con la hija de Piero Bini. Véanse a la izquierda del cuadro el blasón de la familia Pucci con la cabeza de moro, y a la derecha parece de nuevo enlazado al escudo de la familia Bini. Ambas familias pertenecían a una casta de ricos comerciantes. Los Medicis gobernaban desde 1434 apoyados por los Pucci que se habían enriquecido a su sombra en la República. Antonio Pucci, había defendido los intereses de la familia más poderosa mediando entre conflictos a través de alianzas matrimoniales, con enemigos de Piero de Medici, así que no es de extrañar que el propio Lorenzo el Magnífico, en agradecimiento, asumiese el papel de casamentero

51 BOCCACCIO, G.: Decamerón. opus cit.,págs. 404-405.

52 BOCCACCIO, G.: Decamerón. opus cit.,pág. 579.

53 HAGEN, R y R.M.: Los secretos de las obras de arte. opus cit., págs. 80-86.

54 RAQUEJO GRADO, T.: Botticelli. Historia 16, Madrid, 1993. 
en esta boda, de ahí que en el centro del cuadro aparezca el escudo de los Medici.

En Florencia se acostumbraba a decorar las habitaciones principales de las casas nobles con spallieras o casetones de madera que revestían las paredes para protegerlas del frío, la humedad o para empotrar en ellas muebles de adornos ricos. Los casetones destinados a ser pintados en forma de cuadrángulo se distribuían por la habitación uno por cada pared. En los dormitorios nupciales, lo corriente eran historias de amor que aludían a las virtudes de una mujer o moralejas que condenaba su comportamiento. Véase esto como otra muestra más de la misoginia y el doble rasero al juzgar las conductas femeninas respecto a las masculinas. Así, se encargó este ciclo que estaría destinado a decorar la habitación de la joven pareja en el palacio de los Putti, ya que, cabe recordar que los hijos adultos seguían viviendo en casa del padre y su habitación se redecoraba con motivo nupcial. No es de extrañar en los cuadros la presencia de veneras y conchas simbolizando la virginidad y la sexualidad femenina, utilizadas por el maestro florentino tanto para Venus como para la Virgen.

Las cuatro obras formaban un conjunto unitario que se hallaba hasta 1868 en el Palacio Pucci de Florencia, hasta que en 1967 se separaron, las tres primeras del ciclo, se encuentran en el Prado, en Madrid y la última, la representación de la boda, en una colección particular americana. Los dos primeros representan al joven cuando hace su descubrimiento en el bosque del trágico castigo eterno de los amantes, mientras que le tercero reproduce el banquete y la aparición de nuevo.

Antes de comentar la obra llevada a cabo por Botticelli, cabe decir que se trata de una de estas obras morales. Lo curioso, es el modo de contarlo, que es algo arcaico, utilizando la presencia simultánea del mismo personaje (Nastaglio) varias veces en el mismo cuadro. Además, cada cuadro yuxtapuesto, actúa como una viñeta de cómic, que muestra la evolución de la historia. Estos recursos fueron muy frecuentes en el Gótico italiano, pero en el Quattrocento, cuando se realiza esta serie, ya habían sido desechados por los artistas más avanzados.

La historia del cuento octavo titulada El infierno de los amantes crueles, nos muestra unrelato apasionante que mezcla el fantástico con el amor cortés. Una historia de amor y muerte, que no en vano, es justificada con un supuesto moralizante que no viene a ser más que un fin misógino:

...en los sucesivo, las damas de Rávena fueron mucho más amables, sensibles y complacientes hacia sus amantes. ${ }^{55}$

La historia es la siguiente: en Rávena, donde destacan un grupo de caballeros, el joven Nastagio, ha heredado una consiederable fortuna a la muerte de su padre. Pero se ha enamorado perdidamente de una joven, la hija de Paola Traversari, que es de mayor alcurnia y por tanto lo desprecia:

55 BOCCACCIO, G.: Decamerón. opus cit.,pág. 377. 
...Estaba esta tan fieramente apegada a su cuna, que creía envilecerse amando aun

hombre de nobleza menos antigua que la de su casa... ${ }^{56}$

En tal afirmación advertimos varias claves del relato, por una parte, la unión tradicional de belleza y rango en una mujer, como veremos detenidamente en nuestro capítulo final. Y por otra parte, los nuevos tiempos de los que hemos hablado, en la sugerente cuestión del ascenso de la burguesía, que procuraba uniones con la aristocracia.

El joven Nastaglio, según se cuenta, no consigue, más que rechazo y la ingratitud de la dama ante sus solicitudes. Rechazo a sus atenciones, dispendios y regalos. Así, que enfermo de amor por dicho desprecio, llega a plantearse el suicidio, pero cierto orgullo se lo impide, así que decide gastar sus días cerca de la ciudad, haciendo parecer que se ha marchado a un largo viaje, cuando en realidad lo que hace es vivir ociosamente en el campo de Chiasi, a legua y media de Rávena. Allí, en tiendas de campaña amuebladas, vive lujosamente llevando...

...una existencia divertida, gastando más que nunca y teniendo mesa puesta para cuantos

se presentaban. Cada día disfrutaba de nueva compañía. ${ }^{57}$

De lo que se deduce, que el mal de amores, o debiera ser liviano, o dicha actitud no era más que despecho. Lo cierto es que los recuerdos le siguen atormentando y en estos arrebatos de melancolía, amaba la soledad de tal aguijón en el bosque. La presencia del bosque, no en balde, no es un elemento casual. Ya hemos visto cómo la literatura de Chrètien, y la materia de la Bretaña, le daba un significado mágico, donde a ciertas horas, además de ser puerta al otro mundo, podían suceder acontecimientos fantásticos.

Sueño o realidad, tiene lugar allí un suceso. La aparición de una mujer desnuda y desmelenada, que iconográficamente representa Botticelli en clave de Magdalena, huye y es perseguida por perros mastines que la desgarran, y por un caballero jinete, vestido de negro, que la quiere traspasar para arrancarle el corazón. Nastaglio corta una rama, como aparece el cuadro de Botticelli e intenta impedirlo. Estas acciones se recogen en el primer cuadro y se encuentran separadas por momentos gracias a los enmarques de los troncos de los árboles del bosque de pinos. El joven Nastagio figura de tal modo dos veces.

Pero, es cuando intenta impedirlo, cuando el fantasmal caballero le cuenta que es en vano su intento ya que todo se trata de un castigo divino, que tiene su origen

56 BOCCACCIO, G.: Decamerón. opus cit.,pág. 372.

57 BOCCACCIO, G.: Decamerón. opus cit.,pág. 373. 
en la crueldad de esta dama, que ante sus peticiones amorosas fue la causante de su suicidio. Que transcurrido un tiempo la dama murió y que Dios les castigó a ambos. A él le tocó perseguir lo que tanto amó, como su mayor enemigo, para darle caza, traspasarla con su lanza y arrancarle el corazón, ya que éste había sido duro como una roca y dárselo a los perros. A ella, le tocaba ser perseguida y desgarrada durante tantos años como meses desdeñó el amor del caballero, una y otra vez, muriendo y resucitando, cada viernes a la misma hora en dicho bosque.

Así, en el siguiente cuadro, Nastagio contempla horrorizado cómo los perros dan alcance a la mujer, a la cual el caballero mata y destripa, ofreciendo sus entrañas a los animales. Finalizado el suplicio, la mujer se levanta y la persecución se reanuda, como se observa en las figuritas del último plano del bosque.

Nastaglio, se cuenta: observó bien el sitio y regresó a su casa meditabundo ${ }^{58}$. Es entonces, cuando pide a sus amigos un último favor antes de olvidar definitivamente a su amor. Les pide que convenzan a la familia de Paolo Traversari, su esposa, su hija y a un mayor número posible de parientes a un banquete en aquel pinar mediterráneo, que fielmente al borde del mar pinta el maestro Sandro. Allí colocará sus tiendas y la mesa frente por frente del sitio donde tuvo lugar la aparición.

En el tercer cuadro de Botticelli, aparecen así convocados todos los personajes en una mesa en L, los familiares en el frontal, la amada, vestida de blanco, según los cánones, y las mujeres a la izquierda, a la moda florentina de brocados de mangas anchas y peinados en la línea de Giovana Tournabouni o Esmeralda Brandini. A la derecha aparece Nastaglio recibiendo a los invitados. Para tal disposición Botticelli se toma la licencia narrativa de que aperezcan talados los árboles que aparecen en primer plano en los cuadro I y II, creádose así un espacio, adornado con ricos doseles, que dan cobijo al ágape. El momento representado es el clímax, la persecución que se materializa de nuevo, espantando a los presentes.

Se sigue relantando, que tras la comida, que fue suntuosa y espléndida, se produjo la aparición de la mujer perseguida y el caballero. Los convidados reaccionaron contra el fantasma para defender a la mujer-como aparecen en le cuadro III, en actitud de indignación- pero éste se limitó a contar la misma historia que a Nastaglio. Los convidados recordaron entonces la triste historia de amor del caballeroy su trágico final, y quedaron conmovidos según se cuenta. Cada uno se fue luego a su casa, y a la hija de Traversari:

...fácil le fue juzgar que aquella aventura le interesaba más que a nadie, recordando la cruel insensibilidad con que había pagado las atenciones y asiduidades de un joven que la

58 BOCCACCIO, G.: Decamerón. opus cit.,pág. 375. 
adoraba. Tal impresión causó en su ánimo lo que acababa de presenciar que se vió perseguida

por su enamorado y que los perros le desgarraban la carne. La pobre pasó lo restante de aquel

día soñando despierta, y la noche, en una continua pesadilla... ${ }^{59}$

Con lo que la historia acaba felizmente para Nastaglio, que ve como su amada a partir de entonces, le asegura querer corresponderle para en poco tiempo celebrarse la boda de ambos. Boda que aparece como epílogo en el cuarto cuadro, bajo un banquete nupcial enmarcado en una arquitectura efímera en perspectiva tan del gusto florentino y donde los personajes retratados con el mismo atuendo que en los anteriores aparecen comunicandose a la izquierda ante la mirada de todos. El ascenso social y amoroso queda pues sublimado en una historia de amor y muerte.

Esta obra señala un banquete que remite directamente a las codificadas y organizadas bodas florentinas, donde el intermediario o sensale se encargaba de los preliminares dando a conocer a la autoridad competente el nombre de los esposos.

Un matrimonio entre poderosos círculos tenía sobre todo intereses políticos y económicos entre las dos familias que se fuesen a unir. La mujer aparece pues como un objeto de intercambio que rara vez tenía voz respecto a sus sentimientos. En dicha sociedad patriarcal, la mujer dependía de la autoridad del varón, primeramente del padre, y tras casarse, a la tutela en manos de su esposo.Así en su tratado "Sobre la familia" de 1430, Leon Battista Alberti considera que lo importante de una esposa es la reputación d ela familia, la influencia del padre, la suma de la dote, y la constituciñon de la dama que permita una buena fertilidad, además de la facultad para dirigir una casa, la fidelidad y discreción. ${ }^{60}$

De este modo, tras ahcer público el enlace, se comprobaba si la joven desposada poseía realmente la dote reglamentaria. Los padres previsores suscribían al nacimiento de sus hijas unas cuentas en el Gran Libro de la Monte, la Banca del Estado, que recogerían con intereses a los quince años, edad media del casamiento. Así pues se hacía una comida tradicional, donde los invitados se cruzaban regalos con un mínimo de precio estipulado. Tras la ceremonia, a la novia se le prohibía volver de la iglesia a pie bajo multa. Entonces se llegaba el banquete nupcial donde, el número de invitados era limitado, no más de vienticinco, donde no podía haber más de diez hombres y menos de ocho criados. Véase como justamente se corrobora en el cuadro cuatro de Botticelli. El menú estaba obligado a ser anunciado previamente, y constaba de tres platos para el almuerzo y dos para la cena. Tras la cena, la desposada se despide de sus amigas, en símbolo de

59 BOCCACCIO, G.: Decamerón. opus cit.,pág. 376.

60 HAGEN, R. M. et R.: Los secretos de las obras de arte. opus cit., págs.81-85. 
abandono de la infancia. La primera noche sería respetada ya que es la que sigue al sacramento mientras que la segunda, el matrimonio sería consumado. ${ }^{61}$

Existen otros casos destacados de ilustraciones del Decamerón, como el de Juan Sin Miedo, que más tarde, y formando parte de la Biblioteca Palatina de Heidelberg ${ }^{62}$, sería trasladado a Roma. Este ejemplar posee un valor literario y artístico de primer orden, que con todo, no ha sido reconocido hasta fecha relativamente reciente. Este suntuoso códice contiene el primer ciclo completo de imágenes referidas a las cien historias. Las coloristas ilustraciones del manuscrito son obra de un taller que ya había iluminado otra traducción de Boccaccio de Laurent de Premierfait, el Cas de nobles hommes et femmes (París, Bibliothéque de Arsenal, Ms. 5193). El principal responsable del taller es conocido en el mundo académico como Maestro de la ciudad de las damas, en referencia a otro códice. Al parecer llegó a especializarse en iluminar con inagotable inventiva textos literarios profanos, para los cuales los miniaturistas no habían desarrollado aún modelos maestros. Para ello se concentraba en los momentos clave de la trama, conservando siempre la base narrativa de la misma. Tanto él como sus colaboradores se valen casi siempre de un esquema de composición basado en una estructura biespacial de separación vertical. El comienzo del texto queda entonces señalado por una capitular insertada a la izquierda, bajo el marco de la miniatura. La columna de texto izquierda se ve acompañada de una vara ornamental en la que elegantes hojas y zarcillos de enredadera se vuelcan hacia el interior del libro en ángulo casi recto. Con todo, Boccaccio no sólo era conocido por aquel entonces por el Decamerón. Con su tratado mitológico Genealogía deorum sentó las bases de lo que sería el Renacimiento. A esta concepción del mundo correspondía además el ensalzamiento histórico y moral de personajes destacados, así como la prevención contra toda arrogancia, denunciada en latín por el propio Boccaccio en De casius virus et feminarum illustrium (Sobre hombres y mujeres famosos), y en De claris mulieribus (De mujeres nobles)789. Este último tratado fue traducido al francés por mano anónima en 1401 y publicado con el título Des femmes nobles ${ }^{63}$. Estas breves biografías de mujeres destacadas, basadas en esquemas de la Antigüedad, concluyen con la vida de la reina Juana de Nápoles, en cuya corte residió Boccaccio durante algún tiempo. El poeta dedicó la edición latina de su tratado a una de las damas de su corte, la Condesa de Altavilla. Dicha traducción está basada en un códice de excepcional iluminación conservado en la Biblioteca Nacional de París con el que Jaques Raponde obsequió en 1403 o 1404 al duque Felipe de Borgoña. A excepción de las que adornan los folios 33 a 48, las miniaturas son obra de un artista muy competente, conocido con

61 RAYMONDE DE GANS: Los Tesoros de Florencia. opus cit., pág.17.

62 WALTER, I. F et WOLF, N.: Los manuscritos iluminados más bellos del mundo. opág.cit.nota 92, pág.289. 1414-1419 Lugar de origen París Formato 300 × 225 mm Extensión 328 hojas Lengua francés (traducción del latín) Contenido Colección de narraciones de Boccaccio escritas entre 1349 y 1353, centradas principalmente en la moral amatoria. La traducción francesa es de Laurent de Premierfait y el miniaturista Maestro de la ciudad de las damas y colaboradores lluminación 100 miniaturas de media. Donante Juan Sin Miedo, duque de Borgoña y primer propietario Localización, signatura Roma, Biblioteca Apostólica Vaticana, 1989.

63 WALTER, I. F et WOLF, N.: Los manuscritos iluminados más bellos del mundo. opus cit., pág.292. 
el sobrenombre de Maestro de la Coronación de María. La lujosa ornamentación del manuscrito, obra de su prolífico taller parisino, bebe de ilustraciones anteriores de textos de Boccaccio, si bien su lenguaje de formas se decanta por un estilo muy francés, delicado, amanerado en ocasiones. El colorido es suave y rico en matices, y las figuras se mueven por escenarios rebosantes de detalles realistas. El director del taller, a cuyo pincel se debe por ejemplo la imagen de la reina Juana de Napóles (fol. i65v), era partidario de composiciones equilibradas y simétricas, insertadas en un fondo de cuadrículas blancas y negras. Otro miniaturista, autor de la ilustración de la hechicera Circe (fol. 54v), prefería como fondo paisajes exóticos.

Puede decirse que muchos, si no todos los artistas implicados en la iluminación del códice de Boccaccio, tenían experiencia en la pintura de retablos; posiblemente conociesen la obra de Robert Campin. Por lo demás, muchas de sus ideas tienen su origen en el repertorio del gótico internacional de comienzos del siglo XV y en el arsenal de modelos del Maestro de Boucicaut y de los hermanos Limburg. ${ }^{64}$ El Maestro del Boccaccio de Ginebra, identificado recientemente como Colín d'Amiens, tiene una mayor relevancia artística. Las biografías de hombres y mujeres famosos que él y sus colaboradores iluminaron para un cliente desconocido fueron traducidas al francés en 1409 por el ya mencionado Laurent de Premierfait. Todas las magníficas miniaturas del manuscrito presentan los rasgos característicos del artista. En especial los detalles fisiognómicos resultan muy reveladores: cabezas voluminosas, casi cúbicas, sobre unas figuras serias y melancólicas, poseedoras con todo de cierta gracilidad. A su vez, los paisajes ante los que transcurren las vivaces historias hacen gala de enorme variedad, por bien que la luz incide siempre sobre la escena de izquierda a derecha y la ilumina con sobriedad. Numerosos contemporáneos sitúan a Colin d'Amiens, pintor de la corte del rey Luis $\mathrm{XI}$, a la misma altura que a Jean Fouquet, el Maestro de Moulins, Bartholomy de Eyck ${ }^{65}$.

64 PANOFSKY, E.: Los primitivos flamencos. opus cit.,pág. 34. Sobre Jean Pucelle iluminador, pág.49 Grandes Horas duque de Berry, Jean Bodol, págs. 286 y 287 y retratos de Van der Weyden.

65 WALTER, I. F et WOLF, N.: Los manuscritos iluminados más bellos del mundo.opus cit.pág. 291 